\title{
Brand Ambassador and Brand Personality on Decision to Purchase Nature Republic in Karawang
}

\author{
Evi Pebriyanti ${ }^{1}$, Odang Kusmayadi ${ }^{2}$ \\ Universitas Singaperbangsa Karawang ${ }^{1,2}$ \\ JI. HS. Ronggowaluyo, Telukjambe Timur, Karawang ${ }^{1,2}$ \\ e-mail: evi.pebriyanti16140@student.unsika.ac.id ${ }^{1}$, Odang.kusmayadi@feb.unsika.ac.id ${ }^{2}$ \\ Author Notification \\ 22 June 2021 \\ Final Revised \\ 15 November 2021 \\ Published \\ 1 January 2022
}

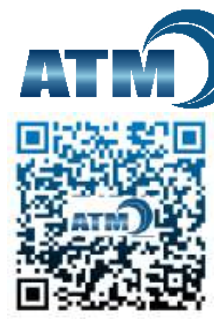

To cite this document :

Pebriyanti, E., \& Kusmayadi, O. (2022). Brand Ambassador and Brand Personality on Decision to Purchase Nature Republic in Karawang. Aptisi Transactions on Management (ATM), 6(1), 83-90.

DOI :

https://doi.org/10.33050/atm.v6i1.1565

\begin{abstract}
Cosmetics have become a necessity for society, especially women. The country that is currently famous for its cosmetic products is South Korea. The famous Korean cosmetic product in Indonesia is Nature Republic. In 2019, Nature republic's sales experienced a very drastic decline. Strategies that can be used to increase sales are Brand Ambassador and Brand Personality. The method used in this research is quantitative research methods. This research uses descriptive research with a quantitative approach. A sample of 270 respondents. The sampling technique used was stratifed sampling. The results showed that Brand Ambassador and Brand Personality had a strong enough correlation, namely 48.8\%, partially Brand Ambassador to purchasing decisions had an effect of $7.6 \%$, partially Brand Personality on purchasing decisions had an effect of 54.9\% and simultaneously Brand Ambassador and Brand Personality for Purchase Decision by 62.5\%. Meanwhile, 37.5\% was influenced by other variables which were not researched. There is a Partial Influence of Brand Personality (X2) on Purchase Decisions (Y) for Korean Nature Republic Cosmetics Users in Karawang Regency of 0.549 or $54.9 \%$. This shows that Brand Personality (X2) contributes or has a positive effect on Purchasing Decisions (Y). The simultaneous influence of Brand Ambassador (X1) and Brand Personality (X2) on Purchase Decisions $(Y)$ of Korean Nature Republic Cosmetics Users in Karawang Regency is 0.625 or $62 \%$, while the remaining $37.5 \%$ is influenced by variables not studied. This shows that Brand Ambassador (X1) and Brand Personality (X2) together have an influence on the Company's Purchasing Decision ( $Y$ ). Korean Cosmetics User Nature Republic in Karawang Regency.
\end{abstract}

Keywords: Ambassador, Personality, Nature Republic

\section{Introduction}

Competition between cosmetic industry companies is getting tighter because cosmetics have become a necessity for the community, especially women. In Indonesia, there has been a shift in the use of beauty products. Many Indonesians, especially women, use imported cosmetics. The country that is currently famous for its cosmetic products which is starting to go global is South Korea. Reported from this, the newspaper [1] stated that the trend of using beauty products is no longer oriented to products originating from the West and has begun to shift to Asian products, especially South Korea [2].

South Korean culture in recent years has become a culture that is quite popular with the people, especially Indonesia. One of the famous Korean cosmetic products in Indonesia is Nature Republic. There is no doubt about the popularity of Nature Republic in Indonesia. Nature Republic is a cosmetic brand that originates from the Ginseng Country, namely South Korea, which is popular with the main ingredient of its products, namely using aloe vera. One of its very popular products is Nature Republic 92\% Shooting Gel. 


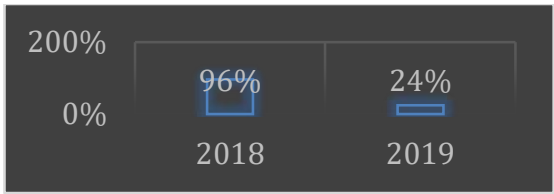

Image 1

Nature Republic Sales Chart 2018 - 2019

Source: trends.google.co.id, 2020, Data Processing 2020

Based on the picture above, in 2019 Nature republic's sales experienced a very drastic decline. Looking at this data, it can be seen that some consumers have started to switch to other beauty products. Nature Republic must pay attention to this by looking for marketing strategies that can attract consumers' attention so that consumers decide to buy back Nature Republic products.

Decisions made by consumers regarding the products to be purchased later are important for the company, because this can determine the amount of revenue that the company can get. Currently, there are so many manufacturers of beauty products, making it difficult for consumers to choose products that suit their needs. follows:

Philip Kotler and Keller [3], the decision dimension consists of 5 dimensions, namely as

- Brand, consumers have to make decisions about what brands to buy.

- Distributor, the customer must determine where the selected dealer to buy the product. The reason consumers choose a distributor is usually due to factors of close location, low prices, complete availability of goods and convenience when buying

- Quantity, consumers can determine the quantity of goods to be purchased. In this case the company must prepare the number of products the desires of different consumers

- Time, when consumers determine the time of purchase can vary, namely conformity to needs, perceived benefits, and reasons for purchase,

- Payment methods, consumers can determine the payment method that will be used when making a purchase. Consumers can use payment methods.

Companies can carry out a strategy in marketing their products by using Brand Ambassadors. For a company, the use of a Brand Ambassador is a strategy used to attract consumers' attention. Companies usually use public figures in marketing activities to attract consumer interest [4].

Brand Personality is someone who has signed a contract to work with a company whose purpose is to promote the company's products. [5] Nature Republic uses EXO as its Brand Ambassador, EXO is a Korean boy group that is currently on the rise.

Some consumers may be influenced to buy products because they have a sense of trust in what is conveyed by the model or artist who advertises or promotes the product. Moreover, if the advertising model is his idol, the greater the chance that consumers will buy the products being sold.

Article released by Marketeers with K-Pop influences, K-drama and brand ambassadors also inspire Indonesian consumers to have healthy skin [6]. By using EXO as the brand ambassador, Nature Republic hopes to win the cosmetics market. The following are data on Top Korean Cosmetics along with Brand Ambassadors that show the level of popularity of Korean cosmetic brands which are shown in the following table:

Table 1

Top Korean Cosmetics in Indonesia in 2019

\begin{tabular}{ccc}
\hline $\begin{array}{c}\text { Rankin } \\
\mathbf{g}\end{array}$ & Product & Brand Ambassador \\
\hline $\mathbf{1}$ & Etude House & SNSD's Yoona \\
\hline $\mathbf{2}$ & Laneige & Kim Yoo Jung \\
\hline $\mathbf{3}$ & Innisfree & Krystal F $(X)$ \\
\hline $\mathbf{4}$ & The Face Shop & Bae Suzy \\
\hline $\mathbf{5}$ & Nature Republic & EXO \\
\hline
\end{tabular}

ATM Vol 6, No. 1 January 2022: 83-90 
It can be seen from the table above that the first place for Korean cosmetics in Indonesia is Etude House, while the fifth place is Nature Republic. This means that even though Nature Republic is one of the products that are already familiar to the public, Nature Republic is still unable to compete with other Korean beauty products.

It can be seen from the table above that Nature Republic competitors use Korean female artists to become Brand Ambassadors, competitors use Korean female artists who are on the rise as Brand Ambassadors. Indeed, in general, cosmetic users are women, so if Nature Republic uses boy groups as brand ambassadors, the boy group chosen by Nature republic is Exo. This Korean boy group has been the Brand Ambassador of Nature Republic ever since

Ossiter and Percy quoted in Kertamukti [7]. Brand Ambassador has 4 dimensions, namely as follows:

- Visibility

has a dimension of how popular the celebrity represents the product. When it comes to popularity, it can be determined by how many fans the celebrity brand ambassadors (Popularity) have and how often they appear in public (Appearance).

- Credibility

a celebrity has more to do with two things, namely expertise and objectivity. This expertise will be related to the celebrity knowledge of the advertised product. While objectivity refers more to the ability of celebrities to give confidence or confidence in consumers of a product. Capable celebrities whose credibility has been trusted will represent the advertised brand. The advertised product will match the perception that the audience wants.

- Attractiveness

The reception of the message depends on the attractiveness of the brand ambassador. Brand Personality will be successful in changing consumer opinions and behavior through the mechanism of attraction.

- Strength

This last dimension informs that a celebrity who is used in an advertisement must have the power to "order" the target audience to buy. Power is the extent to which celebrities are able to persuade consumers and consider advertised products for consumption. [8]

Apart from Brand Ambassadors, companies can also implement Brand Personality strategies to attract consumers' attention. Kotler and Armstrong [9] states that "Brand Personality (brand personality) is a combination of human traits that can be applied to a brand".

Brand Personality is used to differentiate a product from other products. Brand personality is one of the factors that can influence consumer behavior. Companies must make their products have characteristics that other products don't have. The goal with this distinction is that consumers remember the products being marketed so that sales can increase. The brand personality of a product can be in the form of packaging, raw materials, slogans and others. [10]

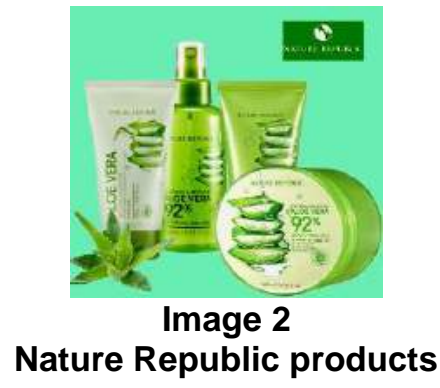

This can be seen from picture 2 [11] of the packaging of several Nature Republic products that have a green appearance and there is an image of aloe vera in each product. the basic ingredient is aloe vera. In accordance with the slogan "Back To Nature", which means that Nature Republic products use natural ingredients, because the ingredients used are Nature Republic, so the level of risk of negative side effects is only small.

Nature Republic is very popular with aloe vera as a base for its products. This is what Nature Republic characterizes so that when consumers want to look for beauty products made from natural ingredients, especially aloe vera, what comes to mind is Nature Republic, because 
in Nature Republic's packaging there is an image of aloe vera on it. product packaging which means that Nature Republic products contain natural ingredients.

The Nature Republic brand is gaining popularity because its products are made from aloe vera, but over time the nature republic's products have begun to be imitated by its competitors, many competitors have started to come up with the same product as Nature Republic, namely Aloevera Gel that is Soothing. This made Nature Republic begin to experience a decline in sales and popularity. follows:

Aeker [12] quoted from the journal [13] The dimensions of Brand Personality are as

- Dimensions of Sincerity, Sincerity is expressed in honesty in the quality of a product, product authenticity and brand identity with a simple nature.

- The Excitement, the dimension shows a pleasant or exciting personality. Describing dynamic characters who are full of passion and high imagination in making a difference and innovating.

- Competencies, dimensions, describe the personality or skills that can be relied on.

- The Saphistication dimension is the personality dimension that makes up a satisfying experience. Water with an exclusivity shaped by the excellence of Brand Personality, and a dazzling level of attractiveness.

- The toughness dimension is to describe a tough personality. The characters in this dimension are brands related to the benefits of a product brand in supporting activities outside the home or the strength of the product.

\section{Research Method}

The method used in this research is a quantitative research method Sugiyono [14]. The quantitative method is called the traditional method, because this method has been used for a long time so that it has traditionally been a research method. This research approach uses descriptive research with a quantitative approach. Quantitative descriptive research is research that aims to obtain an overview and information about the responses of users of Nature Republic cosmetics in Karawang [15]. The data obtained in the study were analyzed the statistical method used. [16]

Darmawan quoted from the journal, the population is a large and extensive source of data in certain studies. [17]. In this study, the population used by researchers was the people of Karawang Regency, to be precise women aged 15 - 34 years with a total of 395,663 people. The following table shows the population in Karawang Regenc.

Table 2

Total Population of Karawang 2018

\begin{tabular}{cc}
\hline Age group & Total Population \\
\hline $\mathbf{1 5 - 1 9}$ Years & 99,428 \\
\hline $\mathbf{2 0 - 2 4}$ Years & 97,952 \\
\hline $\mathbf{2 5}-\mathbf{2 9}$ Years & 98,515 \\
\hline $\mathbf{3 0}-\mathbf{3 4}$ Years & 100,268 \\
\hline TOTAL & $\mathbf{3 9 5 , 6 6 3}$ \\
POPULATION &
\end{tabular}

Source: Bps Karawang, compiled by the author 2020

Sugiyono [18] The sample is part of the number and characteristics of the population. When the population is large and it is impossible for researchers to study everything in the population. Sampling was conducted by researchers using the calculation formula Issac and Michael with the results obtained by 270 respondents who will be sampled.

The sampling technique used in this study was stratified sampling. Suharsimi Arikunto [19] Stratified Sampling is sampling by dividing the population into several levels or strata, such as education level, age level and social class level. Then sampling should not be done randomly. In this study, the sample used is based on the age level or strata. 
3. Results and Analysis

a. Reliability Test

Table 3

Reliability Test Results

\begin{tabular}{|c|c|c|c|c|}
\hline $\begin{array}{l}\mathbf{N} \\
\text { o. }\end{array}$ & Variabel & Rcount & Rcritical & Criteria \\
\hline 1 & Brand Ambassador (X1) & 0.766 & 0.60 & Reliable \\
\hline 2 & Brand Personality (X2) & 0.755 & 0.60 & Reliable \\
\hline 3 & Purchase Decision $(\mathrm{Y})$ & 0.751 & 0.60 & Reliable \\
\hline
\end{tabular}

Based on the table above, it can be seen that the results of the Reliability Test show that each Variable Brand Ambassador (X1), Brand Personality (X2) and Purchase Decision (Y), Cronbach's alpha value $>0.60$, so the Brand Ambassador variable (X1), Brand Personality ( X2) and Purchase Decision $(\mathrm{Y})$ are declared reliable

b. Normality Test

Table 4

Normality Test Results

\begin{tabular}{|c|c|c|c|}
\hline \multirow{2}{*}{ Variable } & \multicolumn{2}{|c|}{ Kolmogorov - Snirnov } & \multirow{2}{*}{ Criteria } \\
\hline & $\alpha$ count & $\alpha$ critical & \\
\hline Brand A & 0.20 & 0.05 & Normal Dist \\
\hline Brand Personality (X2) & 0.20 & 0.05 & Normal Distribution \\
\hline Purchase Decision (Y) & 0.08 & 0.05 & Normal Distribution \\
\hline
\end{tabular}

Source: SPSS Processing Results, compiled by the Author 2020 [20]

Based on the table above shows the results of the reliability test, it is known that the variable Brand Ambassador (X1), Brand Personality (X2), purchase decisions $(\mathrm{Y})$ follow the normal data distribution because the significance of $\alpha$ count is more than 0.05. then Brand Ambassador (X1), Brand Personality $(\mathrm{X} 2)$, purchase decision $(\mathrm{Y})$ following the normal distribution.

c. Correlation between Brand Ambassador (X1) and Brand Personality (X2)

Correlation analysis is the analysis used to determine the degree of the correlation between the independent variables and the correlation analysis used in this study is the product moment correlation. For more details, the correlation between the two exogenous variables can be seen in the following table:

Table 5

\begin{tabular}{|c|c|c|c|}
\hline & avo & $\begin{array}{c}\text { (X1) and Brand } \\
\text { Brand } \\
\text { Ambassador } \\
\text { (X1) }\end{array}$ & $\begin{array}{l}\text { Personality (X } \\
\text { Brand } \\
\text { Personality } \\
\text { (X2) }\end{array}$ \\
\hline \multirow{3}{*}{$\begin{array}{c}\text { Brand } \\
\text { Ambassador } \\
\text { (X1) }\end{array}$} & $\begin{array}{l}\text { Pearson } \\
\text { Correlation }\end{array}$ & 1 &, $488^{* *}$ \\
\hline & Sig. (2-tailed) & & ,000 \\
\hline & $\mathrm{N}$ & 270 & 270 \\
\hline \multirow[t]{3}{*}{$\begin{array}{c}\text { Brand } \\
\text { Personality (X2) }\end{array}$} & $\begin{array}{l}\text { Pearson } \\
\text { Correlation }\end{array}$ &, $488^{* *}$ & 1 \\
\hline & Sig. (2-tailed) & ,000 & \\
\hline & $\mathrm{N}$ & 270 & 270 \\
\hline
\end{tabular}

${ }^{* *}$. Correlation is significant at the 0.01 level (2-tailed).

Source: SPSS Processing Results, compiled by the Author 2020 [20] 
Based on the table above, the coefficient value between the independent variables, namely Brand Ambassador (X1) and Brand Personality (X2) is 0.488 or $48.8 \%$. Thus, Brand Ambassador (X1) and Brand Personality (X2) have a strong and unidirectional correlation because they are both positive.

d. Partial Influence of Brand Ambassador (X1) on Purchasing Decisions (Y)

The direct or indirect effect of Brand Ambassador (X1) on Purchasing decisions (Y) Can be seen in the following table:

Table 6

Partial Influence of Brand Ambassador (X1) on Purchasing Decisions (Y)

\begin{tabular}{cccc}
\hline Variable & Interpretation of Direct & Calculation & $\begin{array}{c}\text { Magnitude of } \\
\text { Influence }\end{array}$ \\
\hline $\begin{array}{c}\text { Brand } \\
\text { Ambassad } \\
\text { or (X1) }\end{array}$ & Direct Influence X1 ke Y & $0,153^{2}$ & 0,023 \\
\cline { 2 - 4 } & Indirect Influence X1 ke Y & $\begin{array}{c}0,153 \times 0,488 \times \\
0,704\end{array}$ & 0,053 \\
\cline { 2 - 4 } & & & 0,076
\end{tabular}

Source: SPSS Processing Results, compiled by the Author 2020 [20]

Based on the table above, it can be seen that the Brand Ambassador (X1) variable on the Purchase Decision ( $\mathrm{Y}$ ) has an effect of 0.076 or $7.6 \%$.

e. Partial Influence of Brand Personality (X2) on Purchasing Decisions (Y)

The direct or indirect effect of Brand Personality (X2) on Purchasing Decisions (Y) can be seen in the following table:

Table 7

Partial Influence of Brand Personality (X2) on Purchasing Decisions (Y)

\begin{tabular}{cccc}
\hline Variabel & $\begin{array}{c}\text { Interpretation of path } \\
\text { analysis }\end{array}$ & Calculation & $\begin{array}{c}\text { Magnitude } \\
\text { of } \\
\text { Influence }\end{array}$ \\
\hline $\begin{array}{c}\text { Brand } \\
\begin{array}{c}\text { Personality } \\
\text { (X2) }\end{array}\end{array}$ & Direct Influence X2 ke Y & 0.7042 & 0.496 \\
\cline { 2 - 4 } & Indirect Influence X2 ke Y & $\begin{array}{c}0.704 \times 0.488 \times \\
0.153\end{array}$ & 0.053 \\
\cline { 2 - 4 } & TOTAL & & 0.549
\end{tabular}

Source: Data Processing Results, processed by the Author 2020 [20]

Based on the table above, it can be seen that the Brand Ambassador (X1) variable on the Purchase Decision $(\mathrm{Y})$ has an effect of 0.549 or $54.9 \%$.

f. Simultaneous Influence of Brand Ambassador (X1) and Brand Personality (X2) on Purchasing Decisions $(\mathrm{Y})$

The simultaneous influence of Brand Ambassador (X1) and Brand Personality $(\mathrm{Y})$ can be seen in the following table:

Table 8

The Simultaneous Influence of Brand Ambassador (X1) and Brand Personality (X2) on Purchasing Decisions $(Y)$

\begin{tabular}{cccccc} 
Variabel & $\begin{array}{c}\text { Coefficient } \\
\text { Path }\end{array}$ & $\begin{array}{c}\text { Direct } \\
\text { Influence }\end{array}$ & \multicolumn{2}{c}{ Indirect Influence } & Sub-Total \\
& & $\mathbf{X 1}$ & $\mathbf{X 2}$ & Influence \\
\hline $\begin{array}{c}\text { Brand } \\
\text { Ambassador } \\
\text { (X1) }\end{array}$ & 0,153 & 0,023 & $\ldots$ & 0,053 & 0,076 \\
\hline & & & & &
\end{tabular}




\begin{tabular}{ccccc}
\hline $\begin{array}{c}\text { Brand } \\
\begin{array}{c}\text { Personality } \\
\text { (X2) }\end{array}\end{array}$ & $0,704 \quad 0,496 \quad 0,053$ & $\ldots .$. & 0,549 \\
\hline \multicolumn{4}{c}{ Total Simultaneous Influence } \\
\hline \multicolumn{3}{c}{ Other Influence from outside 1 - 0.625 } & 0,625 \\
\hline
\end{tabular}

Source: Data Processing Results, processed by the Author 2020 [20]

The table shows that the total influence of Brand Ambassador (X1) and Brand Personality (X2) on Purchasing Decisions $(\mathrm{Y})$ has an effect of 0.625 or $62.5 \%$, while the influence of other variables is $1-0.625=0.375$ or $37.5 \%$.

The effect of the total variable Brand Ambassador (X1) and Brand Personality (X2) on purchasing decisions $(Y)$ is the coefficient of determination $\mathrm{R}$ can be seen in the following table:

Table 9

The coefficient of determination on the correlatios between variables

\begin{tabular}{ccccc}
\hline Model & $\mathbf{R}$ & $\begin{array}{c}\boldsymbol{R} \\
\text { Square }\end{array}$ & $\begin{array}{c}\text { Adjusted } \boldsymbol{R} \\
\text { Square }\end{array}$ & $\begin{array}{c}\text { Std. Error of the } \\
\text { Estimate }\end{array}$ \\
\hline $\mathbf{1}$ &, $791^{\text {a }}$ &, 625 &, 622 & 521,730 \\
\hline
\end{tabular}

Source: Data Processing Results, processed by the Author 2020 [20]

Based on the table above, it shows that the coefficient of determination FFI (R) of 0.625 means that $62.5 \%$ of the Purchasing Decision variable $(\mathrm{Y})$ can be explained by Brand Ambassador (X1) and Brand Personality (X2), or it can be interpreted that Brand Ambassador ( $\mathrm{X} 1$ ) and Brand Personality (X2) contributed $62.5 \%$ to the Purchase Decision (Y), while the remaining $37.5 \%$ was the contribution of other variables $(\varepsilon)$ which were not studied.

\section{Conclusion}

The correlation coefficient between Brand Ambassador (X1) and Brand Personality (X2) can be assessed as 0.488 . Thus, Brand Ambassador (X1) and Brand Personality (X2) have a strong and unidirectional correlation because they are positive with a coefficient interval of $0.30-0.599$ with a fairly strong category.

There is a Partial Effect of Brand Ambassador (X1) on Purchase Decisions (Y) on Korean Nature Republic Cosmetics Users in Karawang Regency of 0.076 or $7.6 \%$. This shows that the Brand Ambassador variable has a positive effect on Purchasing Decisions.

There is a Partial Influence of Brand Personality (X2) on Purchase Decisions (Y) for Korean Nature Republic Cosmetics Users in Karawang Regency of 0.549 or $54.9 \%$. This shows that Brand Personality (X2) contributes or has a positive effect on Purchasing Decisions (Y).

The simultaneous influence of Brand Ambassador (X1) and Brand Personality (X2) on Purchase Decisions ( $Y$ ) of Korean Nature Republic Cosmetics Users in Karawang Regency is 0.625 or $62 \%$, while the remaining $37.5 \%$ is influenced by variables not studied. This shows that Brand Ambassador (X1) and Brand Personality (X2) together have an influence on the Company's Purchasing Decision (Y). Korean Cosmetics User Nature Republic in Karawang Regency. 


\section{References}

[1] R. Wade, Governing the market. Princeton University Press, 2018.

[2] T. Mihailovic, T. Vescovi, and A. Pontiggia, "The Beauty Ideal in Chinese Luxury Cosmetics: Adaptation Strategies of Western Companies," Dep. Manag. Univ. Ca'Foscari Venezia Work. Pap., no. 2017/07, 2017.

[3] M. Sembiring, "MODEL ANALYSIS OF PURCHASE DECISION," Dinasti Int. J. Manag. Sci., vol. 1, no. 3, pp. 390-406, 2020.

[4] E. Sharma, "A review of corporate social responsibility in developed and developing nations," Corp. Soc. Responsib. Environ. Manag., vol. 26, no. 4, pp. 712-720, 2019.

[5] R. Rutter, K. J. Chalvatzis, S. Roper, and F. Lettice, "Branding instead of product innovation: a study on the brand personalities of the UK's electricity market," Eur. Manag. Rev., vol. 15, no. 2, pp. 255-272, 2018.

[6] N. Azizah and A. Dwiyanti, "South Korea in Reconstructing Masculinity as Brand Image of the State's Economic Diplomacy," 2021.

[7] R. M. Nisrina and H. Juanim, "PENGARUH BEAUTY VLOGGER SEBAGAI INFLUENCER MARKETING DAN CITRA MEREK TERHADAP KEPUTUSAN PEMBELIAN KOSMETIK L'OREAL DI COUNTER MATAHARI DEPARTEMENT STORE BANDUNG INDAH PLAZA (Survey Pada Pengunjung L'oreal di Counter Matahari Departement Store Bandung Indah Plaza)." Perpustakaan Fakultas Ekonomi dan Bisnis Unpas Bandung, 2019.

[8] W. Yang, "Star power: the evolution of celebrity endorsement research," Int. J. Contemp. Hosp. Manag., 2018.

[9] V. Pahwa, "IMPACT OF BRAND EXTENSION ON BRAND PERSONALITY."

[10] F. J. F. Coelho, C. M. Bairrada, and A. F. de Matos Coelho, "Functional brand qualities and perceived value: The mediating role of brand experience and brand personality," Psychol. Mark., vol. 37, no. 1, pp. 41-55, 2020.

[11] N. C. Lubis and M. Ariyanti, "Effect of celebrity endorsement, EWOM and brand image on purchase decision of Nature Republic products in Indonesia," in Managing Learning Organization in Industry 4.0, Routledge, 2020, pp. 22-26.

[12] D. A. Aaker and C. Moorman, Strategic market management. John Wiley \& Sons, 2017.

[13] S. C. Morrish, L. Pitt, J. Vella, and E. Botha, "Where to visit, what to drink? A cross-national perspective on wine estate brand personalities," Int. J. Wine Bus. Res., 2017.

[14] N. M. Nugraha and M. R. Riyadhi, "The Effect of Cash Flows, Company Size, and Profit on Stock Prices in SOE Companies Listed on Bei For the 2013-2017 Period," Int. J. Innov. Creat. Chang., vol. 6, no. 7, pp. 130-141, 2019.

[15] A. Atsar, "Legal Protection of Industrial Design Information and Communication Technology Based on Creative Economy to Improve Community Competitiveness," Yuridika, vol. 34, no. 2, pp. 195-214, 2019.

[16] A. Queirós, D. Faria, and F. Almeida, "Strengths and limitations of qualitative and quantitative research methods," Eur. J. Educ. Stud., 2017.

[17] I. G. N. Darmawan, "The changes in attitudes of 15-year-old Australian students towards reading, mathematics and science and their impact on student performance," Aust. J. Educ., vol. 64, no. 3, pp. 304-327, 2020.

[18] B. S. Irianto, Y. A. Sudibyo, and A. Wafirli, "The influence of profitability, leverage, firm size and capital intensity towards tax avoidance," Int. J. Account. Tax., vol. 5, no. 2, pp. 33-41, 2017.

[19] L. Fikriyah, "The analysis of education level and unemployment's influence toward the poverty." Universitas Islam Negeri Maulana Malik Ibrahim, 2017.

[20] S. Kot and I. Rajiani, "Testing and identifying variable dependency through the Fisher exact test in central Europe enterprises," Ekon. spektrum, vol. 14, no. 1, pp. 10-18, 2020. 